\title{
Implementasi Metode Algoritma Genetika Pada Penentuan Menu Makanan Untuk Membentuk Berat Badan Ideal
}

\author{
Christopher Nanda Jonathan \\ Program Studi Teknik Informatika \\ Jurusan Teknologi Informasi \\ Politeknik Negeri Jember \\ Jember, Indonesia \\ cnjonathan.cnj@gmail.com \\ Agung Rahmatullah \\ Program Studi Teknik Informatika \\ Jurusan Teknologi Informasi \\ Politeknik Negeri Jember \\ Jember, Indonesia \\ agungrahmatullah661@gmail.com \\ Ardhan Febriansyah \\ Program Studi Teknik Informatika \\ Jurusan Teknologi Informasi \\ Politeknik Negeri Jember \\ Jember, Indonesia \\ febriansyahardhan@gmail.com
}

\author{
Vyan Ary Pratama \\ Program Studi Teknik Informatika \\ Jurusan Teknologi Informasi \\ Politeknik Negeri Jember \\ Jember, Indonesia \\ vyanaryprabowo9763@gmail.com \\ Panji Budi Satria \\ Program Studi Teknik Informatika \\ Jurusan Teknologi Informasi \\ Politeknik Negeri Jember \\ Jember, Indonesia \\ panjibudi467@gmail.com \\ Trismayanti Dwi Puspitasari \\ Program Studi Teknik Informatika \\ Jurusan Teknologi Informasi \\ Politeknik Negeri Jember \\ Jember, Indonesia \\ trismayanti@polije.ac.id
}

\author{
Lutfi Auliasari \\ Program Studi Teknik Informatika \\ Jurusan Teknologi Informasi \\ Politeknik Negeri Jember \\ Jember, Indonesia \\ lutfiauliasari23@gmail.com \\ Roifatul Munawaroh \\ Program Studi Teknik Informatika \\ Jurusan Teknologi Informasi \\ Politeknik Negeri Jember \\ Jember, Indonesia \\ roifatulmunawaroh95@gmail.com
}

\begin{abstract}
Human need balanced nutrition to grow up. It contained various nutrients namely energy, protein, vitamins, and minerals. Data from the Ministry of Health, the proportion of overweight in adults above 18 years old on 2018 amounted to $13 \%$, while data from Basic Health Research mentions that adults with nutritional deficiencies amounted to $12.6 \%$. This shows that many adults do not pay attention to the food with balanced nutrition that can lead to obesity and nutritional deficiencies. To prevent this, it can be done by eating healthy food that contains enough calories. Someone needs different calories according to the age, height, weight, gender and physical activity. To optimize the level of calory that being consumed daily, we use Genetic Algorithm to obtain more menus with higher calory, the menu will be divided into breakfast, lunch, and dinner, in accordance to the recommended nutritional needs.From this study using Genetic Algorithms, there is an average increase in the number of calories by $88 \mathrm{kcal}$, from $1037 \mathrm{kcal}$ to $1123 \mathrm{kcal}$, and there is one chromosome that satisfies the recommended calorie requirement, which is $1,849 \mathrm{kcal}$.
\end{abstract}

Keywords- food combinations; genetic algorithm; nutritional needs

Abstrak - Manusia membutuhkan nutrisi yang seimbang untuk tumbuh. Itu mengandung berbagai nutrisi yaitu energi, protein, vitamin, dan mineral. Data dari Departemen Kesehatan, proporsi kelebihan berat badan pada orang dewasa di atas 18 tahun pada tahun 2018 berjumlah 13\%, sedangkan data dari Riset Kesehatan Dasar menyebutkan bahwa orang dewasa dengan kekurangan gizi berjumlah $12,6 \%$. Ini menunjukkan bahwa banyak orang dewasa tidak memperhatikan makanan dengan gizi seimbang yang dapat menyebabkan obesitas dan kekurangan gizi. Untuk mencegahnya, hal itu bisa dilakukan dengan mengonsumsi makanan sehat yang mengandung cukup kalori. Seseorang membutuhkan kalori yang berbeda sesuai dengan usia, tinggi, berat badan, jenis kelamin, dan aktivitas fisik. Untuk mengoptimalkan tingkat kalori yang dikonsumsi setiap hari, kami menggunakan Algoritma Genetika untuk mendapatkan lebih banyak menu dengan kalori lebih tinggi, menu akan dibagi menjadi sarapan, makan siang, dan makan malam, sesuai dengan kebutuhan nutrisi yang direkomendasikan. Dari penelitian ini menggunakan Algoritma Genetika. , ada peningkatan rata-rata dalam jumlah kalori sebesar 88 kkal, dari 1037 kkal menjadi 1123 kkal, dan ada satu kromosom yang memenuhi kebutuhan kalori yang disarankan, yaitu 1.849 kkal.

Keywords - kombinasi makanan; algoritma genetika; kebutuhan nutrisi

\section{PENDAHULUAN}

Gizi seimbang merupakan susunan pangan sehari - hari yang mengandung zat gizi dalam jenis dan jumlah yang sesuai dengan kebutuhan tubuh dan memperhatikan prinsip keanekaragaman pangan, aktivitas fisik, perilaku hidup bersih dan mempertahankan berat badan normal untuk mencegah masalah gizi[1]. Gizi seimbang mengandung komponen yang cukup secara kualitas dan kuantitas. Gizi seimbang mengandung berbagai zat gizi yaitu energi, protein, vitamin, dan mineral yang di perlukan untuk tumbuh. Berdasarkan data dari Departemen Kesehatan propors iberat badan lebih (overweight) pada orang dewasa umur>18 tahun 2018 sebesar 13[2]. Dan data dari Riset Kesehatan Dasar menyebutkan bahwa pada orang dewasa untuk kekurangan gizi sebesar 12,6\%[3]. Hal ini menunjukan bahwa banyak orang dewasa tidak paham dan tidak memperhatikan makanan dengan gizi yang seimbang. Akibat dari hal tersebut dapat menyebabkan obesitas dan kekurangan gizi.

Obesitas merupakan salah satu factor terjadinya Penyakit Tidak Menular (PTM) antara lain penyakit jantung, stroke, kanker, diabetes dan Penyakit Paru Obstruktif Kronis (PPOK). Kekurangan gizi atau biasa disebut mal nutrisi juga merupakan akibat dari kebutuhan gizi yang tidak seimbang. 
Mal nutrisi terjadi karena tubuh kekurangan gizi dalam jangka waktu yang lama. Untuk mencegah masalah tersebut dapat dilakukan dengan cara berolah raga, banyak minum air putih dan memakan makanan yang sehat. Makanan yang sehat harus memiliki kadar kalori yang cukup. Kebutuhan kalori seseorang berbeda menurut usia, tinggi badan, berat badan, jenis kelamin dan aktivitas fisik. Untuk mengetahui tingkat kebutuhan kalori berdasarkan usia, tinggi badan, berat badan, jenis kelamin dan aktivitas fisik dibuat system pengaturan menu makanan harian yang akan di makan pada sarapan, makan siang, dan makan malam sesuai dengan Angka Kebutuhan Gizi yang dianjurkan. Pengaturan menu makanan ini menggunakan metode Algoritma Genetika untuk memperoleh kombinasi makanan yang terbaik sehingga kebutuhan kalori dapat terpenuhi. Penggunaan algoritma genetika juga dilakukan penelitian oleh Riska Ayu Permata, Dedi Triyanto dan Ilhamsyah (2016) tentang Aplikasi Penyusun Menu Makanan Untuk Pencegahan Hiperkolesterolemia Menggunakan Algoritma Genetika [14].

Algoritma Genetika merupakan teknik pencarian didalam ilmu komputer untuk menemukan penyelesaian perkiraan untuk optimasi dan masalah pencarian. Algoritma ini berdasarkan pada proses genetik yang ada pada makhluk hidup, yaitu perkembangan generasi sebuah populasi alami yang mengikuti prinsip seleksi alam atau siapa yang kuat dia yang akan bertahan[4]. Pada penelitian sebelumnya yang berjudul "APLIKASI PENYUSUN MENU MAKANAN UNTUK PENCEGAHAN HIPERKOLESTEROLEMIA MENGGUNAKAN ALGORITMA GENETIKA" dimana pada penilitian ini berfokus pada pengaturan menu diet makanan untuk mencegah penyakit hiperkolesterolemia[4]. Sedangkan penelitian dengan judul "OPTIMASI MENU MAKANAN UNTUK PEMENUHAN GIZI PENDERITA KANKER DENGAN ALGORITMA GENETIKA" berfokus pada pengaturan menu makanan bagi penderita kanker untuk memperbaiki status gizi saat melakukan kemoterapi[5]. Perbedaan penelitian ini dengan penelitian sebelumnya yaitu penelitian ini berfokus untuk mengatur menu makanan untuk usia dewasa umur $>18$ tahun sesuai dengan usia, tinggi badan, berat badan, jenis kelamin dan aktivitas fisik sehingga dapat memperoleh berat badan ideal dan terhindar dari obesitas dan kekurangan gizi..

\section{BERAT BADAN IDEAL}

Berat badan ideal secara fisik dapat dilihat dan dinilai dari penampilan luar. Penilaian setiap orang tentunya berbeda, antara orang awam dengan orang yang mempunyai latar belakang medis sangat berbeda. Namun secara umum orang biasanya menilai tubuh sehat ideal, dilihat dari postur tubuh, sikap dan tutur kata serta interaksi orang tersebut dengan orang lain.

a. Postur tubuh ideal

Postur tubuh ideal dinilai dari pengukuran antropometri untuk menilai apakah komponen tubuh tersebut sesuai dengan standard normal atau ideal, seperti yang tercantum pada Tabel I. Pengukuran antropometri yang paling sering digunakan adalah rasio antara berat badan $(\mathrm{kg})$ dan tinggi badan (m) kuadrat, yang disebut Indeks Massa Tubuh (IMT) sebagai berikut[6] :

\section{Berat Badan (kg)}

\begin{tabular}{|c|c|c|c|c|c|}
\hline \multicolumn{6}{|c|}{$\begin{array}{c}\text { Tinggi Badan x Tinggi Badan }(\mathbf{m}) \\
\text { TABEL I } \\
\text { STATUS GIZI }\end{array}$} \\
\hline & $\begin{array}{l}\text { Jenis } \\
\text { Kelamin }\end{array}$ & & $\begin{array}{l}\text { IMT } \\
\left(\mathrm{kg} / \mathrm{m}^{2}\right)\end{array}$ & [3] & Status Gizi \\
\hline \multirow{4}{*}{ [4] } & \multirow{4}{*}{ Laki-laki } & {$[5]$} & $<18$ & {$[6]$} & Kurus \\
\hline & & [7] & $18-25$ & {$[8]$} & Normal \\
\hline & & [9] & $25-27$ & [10] & Kegemukan \\
\hline & & [11] & $>27$ & [12] & Obesitas \\
\hline \multirow{4}{*}{ [13] } & \multirow{4}{*}{ Perempuan } & [14] & $<17$ & [15] & Kurus \\
\hline & & [16] & $17-23$ & [17] & Normal \\
\hline & & [18] & $23-27$ & [19] & Kegemukan \\
\hline & & [20] & $>27$ & [21] & Obesitas \\
\hline
\end{tabular}

Contoh: wanita dengan tinggi badan $161 \mathrm{~cm}$ dan berat $58 \mathrm{~kg}$

$$
58
$$

$$
\text { IMT }=\frac{-1,61 \times 1,61}{1,---22,37}(\text { normal) }
$$

IMT wanita yang normal berada diantara $17-23$. Seorang dikatakan kurus bila IMT nya $<17$ dan gemuk bila IMT nya $>23$. Bila IMT $>27$ orang tersebut menderita obesitas dan perlu diwaspadai karena biasanya orang tesebut juga menderita penyakit degenerative seperti Diabetes Melitus, hipertensi, hiperkolesterol dan kelainan metabolisme lain yang memerlukan pemeriksaan lanjut baik klinis atau laboratorium.

Untuk mengetahui Berat Badan ideal dapat menggunakan rumus Brocca sebagai berikut :

$$
\text { BB Ideal }=(\mathrm{TB}-100)-10 \%(\mathrm{~TB}-100)
$$

Batas ambang yang diperbolehkan adalah 10\%. Bila lebih dari $10 \%$ sudah dapat dikategorikan kegemukan dan bila diatas $20 \%$ sudah terjadi obesitas.

Contoh wanita dengan tinggi $161 \mathrm{~cm}$ dan berat $58 \mathrm{~kg}$, berat badan idealnya jika dihitung dengan rumus di atas adalah 55 $\mathrm{kg}$. Berat badan $58 \mathrm{~kg}$ masih dalam batas $10 \%$, sehingga masih dapat dikategorikan normal.

\section{b. Kebutuhan kalori harian}

Kebutuhan kalori harian adalah jumlah kalori yang dibutuhkan oleh tubuh Anda setiap hari, untuk menjalankan fungsi utama tubuh, dan untuk melakukan aktivitas seharihari. Kebutuhan kalori harian ini bisa Anda gunakan sebagai acuan berapa banyak makanan yang harus Anda konsumsi per harinya. Kebutuhan kalori harian di dapat dari angka BMR yang dikalikan dengan factor aktivitas fisik.

BMR Pria $=66+(13,7 \times$ berat badan $)+(5 x$ tinggi badan $)-(6,8 \times$ usia $)$

BMR Wanita $=655+(9,6 \times$ berat badan $)+(1,8 x$ tinggi badan) - (4,7 $x$ usia)

\section{Keterangan:}

Berat badan dalam kilogram $(\mathrm{kg})$

Tinggi badan dalam sentimeter $(\mathrm{cm})$ 
Untuk memenuhi kebutuhan gizi, manusia dapat mengkonsumsi berbagai macam sayur dan lauk pauk, antara lain seperti yang tercantum pada Tabel III [7].

TABEL II

\section{TABEL KALORI}

\begin{tabular}{|c|c|c|c|}
\hline $\begin{array}{l}\text { Jenis } \\
\text { Makanan }\end{array}$ & No. & Nama Makanan & $\begin{array}{l}\text { Energi } \\
(\mathrm{kkal})\end{array}$ \\
\hline \multirow{7}{*}{ Sayur } & 1. & $\begin{array}{ll}\text { Tumis } & \text { Daun } \\
\text { Singkong } & \\
\end{array}$ & 151 \\
\hline & 2. & $\begin{array}{ll}\text { Tumis } & \text { Kacang } \\
\text { Panjang dan Jagung }\end{array}$ & 118 \\
\hline & 3. & Sayur Lodeh & 61 \\
\hline & 4. & Sayur Asam & 88 \\
\hline & 5. & Sop Bayam & 78 \\
\hline & 6. & Gudeg & 132 \\
\hline & 7. & Tumis Buncis & 52 \\
\hline \multirow{7}{*}{$\begin{array}{l}\text { Lauk } \\
\text { Hewani }\end{array}$} & 1. & Ati Ayam Goreng & 98 \\
\hline & 2. & Bakso Sapi & 260 \\
\hline & 3. & Empal Daging & 147 \\
\hline & 4. & Ikan Lele Goreng & 58 \\
\hline & 5. & Telur Mata Sapi & 40 \\
\hline & 6. & $\begin{array}{ll}\text { Ikan } & \text { Bandeng } \\
\text { Goreng } & \\
\end{array}$ & 181 \\
\hline & 7. & Ikan Teri Goreng & 66 \\
\hline \multirow{7}{*}{$\begin{array}{l}\text { Lauk } \\
\text { Nabati }\end{array}$} & 1. & Tahu Bacem & 147 \\
\hline & 2. & Tempe Bacem & 157 \\
\hline & 3. & Tahu Goreng & 111 \\
\hline & 4. & Tempe Goreng & 118 \\
\hline & 5. & $\begin{array}{ll}\text { Sambal Goreng } \\
\text { Tempe }\end{array}$ & 116 \\
\hline & 6. & Tahu Sumedang & 113 \\
\hline & 7. & Tahu Isi & 124 \\
\hline Pokok & 1. & Nasi & 204 \\
\hline
\end{tabular}

\section{ALGORITMA GENETIKA}

Algoritma Genetika adalah teknik pencarian yang di dalam ilmu computer untuk menemukan penyelesaian perkiraan untuk optimisasi dan masalah pencarian. Algoritma genetika adalah kelas khusus dari algoritme evolusioner dengan menggunakan teknik yang terinspirasi oleh biologi evolusioner seperti warisan, mutasi, seleksialam dan rekombinasi (ataucrossover).

Algoritma genetika (AG) adalah suatu algoritma pencarian yang berbasis pada mekanisme seleksi alam dan genetika. Algoritma genetika merupakan salah satu algoritma yang sangat tepat digunakan dalam menyelesaikan masalah optimasi kompleks, yang sulit dilakukan oleh metode konvensional[7]. berikut.

Tahapan-tahapan algoritma genetika adalah sebagai

\section{a. Teknik Pengkodean}

Pengkodean harus merepresentasikan individu yang akan dicari solusinya. Operator genetic harus dapat diterapkan pada sandi-sandi tersebut. Gen dapat direpresentasikan dalam bentuk biner[8].

\section{b. Membentuk populasi awal}

Membangkitkan populasi awal dipengaruhi oleh jumlah individu. Ukuran populasi dipengaruhi oleh permasalahan yang akan diselesaikan dan operator yang digunakan. Lalu lakukan inisialisasi terhadap kromosom yang ada pada populasi tersebut secara acak.

Pembangkitan populasi awal dapat dilakukan dengan beberapa cara yaitu random generator, pendekatan tertentu dan permutasi gen. Pada penelitian ini membangkitkan populasi awal dilakukan dengan random generator, yaitu membangkitkan populasi secara acak untuk setiap gen sesuai dengan representasi kromosom yang digunakan[9].

\section{c. Evaluasi Nilai Fitness}

Mengevaluasi nilai fitness berfungsi untuk mengukur kualitas dari sebuah solusi dan memungkinkan tiap solusi untuk dibandingkan[10]. Suatu individu dievaluasi berdasarkan suatu fungsi tertentu sebagai ukuran baik tidaknya individu tersebut. Di dalam evolusi alam, individu yang bernilai fitness tinggi yang akan bertahan hidup, sedangkan individu yang bernilai fitness rendah akan mati[11]. Pada masalah pembentukan berat badan ideal, fungsi fitness yang digunakan adalah JikaKalori, ( $\mathrm{K} \leq \mathrm{Kl}$ ) Maka K Tetap

JikaKalori, ( $\mathrm{K}>\mathrm{Kl}$ ) Maka K $-\frac{K-K I}{10}$

Keterangan :

$\mathrm{K}=$ Kalori setiap kromosom

$\mathrm{Kl}=$ Kalori yang dibutuhkan perharinya

\section{d. Seleksi (Route Wheel Selection)}

Operasi seleksi dilakukan dengan memperhatikan fitness dari tiap individu, manakah yang dapat dipergunakan untuk generasi selanjutnya. Seleksi ini digunakan untuk mendapatkan calon induk yang baik, semakin kecil nilai fitnessnya maka semakin kecil juga kemungkinan individu tersebut terpilih. Diantaranya adalah seleksi roulette wheel. Proses seleksi yang biasa digunakan adalah mesin roulette (roulette wheel). Calon induk yang akan dipilih berdasarkan nilai fitness yang dimilikinya, semakin baik individu tersebut yang ditujukkan dengan semakin kecil nilai fitnessnya akan mendapatkan kemungkinan yang lebih kecil untuk terpilih sebagai induk. Misalkan saja roulette wheel merupakan tempat untuk menampung seluruh kromosom dari tiap populasi, maka kecilnya tempat dari roulette wheel tersebut menunjukkan seberapa kecil nilai fitness yang dimiliki oleh suatu kromosom, semakin kecil nilai fitness tersebut, maka semakin kecil pula tempat yang tersedia[12].

\section{e. Crossover}

Crossover adalah operator algoritma genetika yang membutuhkan parameter dua kromosom. Dua buah kromosom tersebut disebut kromosom induk. Operator ini akan menghasilkan dua buah kromosom baru. Ada beberapa jenis crossover yang sering digunakan dalam algoritma genetic aantara lain: One-Point Crossover [13]. Pada metode ini yang pertama dilakukan adalah memilih dua induk yang akan di-crossover lalu menetukan cut point. Satu kali proses crossover menghasilkan satu anak. Anak hasil crossover akan memiliki kromosom dari induk pertama sepanjang cut point, dan mendapatkan kromosom sisanya dari induk kedua[14].Cut point yang digunakan dalam penelitian ini adalah setelah gen ketiga pada kromosom.

\section{f. Mutasi}

Mutasi merupakan proses untuk mengubah nilai dari satu atau beberapa gen dalam suatu kromosom. Operasi mutasi yang dilakukan pada kromosom dengan tujuan untuk memperoleh kromosom-kromosom baru sebagai kandidat 
solusi pada generasi mendatang dengan fitness yang lebih baik, dan lama-kelamaan menuju solusi optimum yang diinginkan. Akan tetapi untuk mencapai hal ini, penekanan selektif juga memegang peranan yang penting[15]. Jika dalam proses pemilihan kromosom-kromosom cenderung terus pada kromosom yang memiliki fitness yang tinggi saja, konvergensi premature akan sangat mudah terjadi[16].

\section{METODE PENELITIAN}

Pada penelitian ini, menggunakan Algoritma Genetika yang pertama kalidikenalkan oleh John Holland untukmenyelesaikan masalah optimasi pemenuhan gizi pada seorang pria yang memiliki berat badan $55 \mathrm{~kg}$ dan tinggi $175 \mathrm{~cm}$. Tahapan algoritma genetika secara umummirip dengan teori evolusi biologis penentukankromosom atau individu dengan kualitas tinggidalam suatu kawasan yang dikenal sebagaipopulasi. secaraumum algoritme genetika memiliki beberapatahapan sebagai berikut:

1. Pengkodean.

2. Pembentukan populasi awal.

3. Evaluasi fitness

4. Proses seleksi

4. Prosescrossover

5. Proses mutasi.

Perancangan sistem pada penelitian inidibuatberdasarkan tahapan pada algoritmegenetika. Alur penyelesaian masalah optimasimenu makanan untuk berat badan ideal ditunjukkan pada Gambar 1.

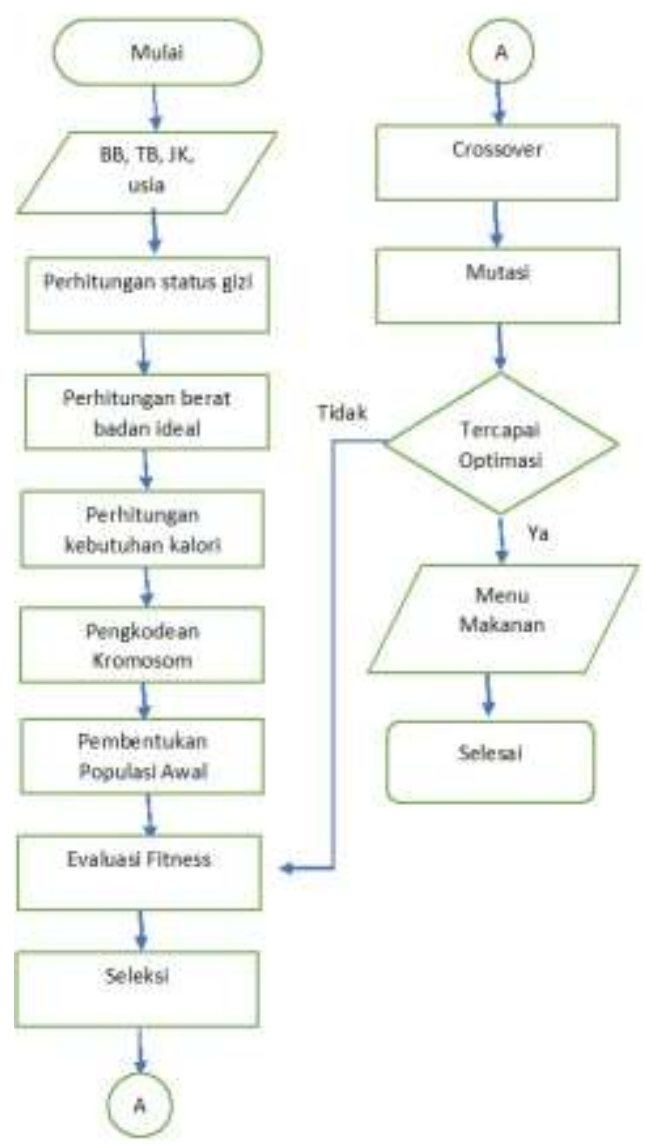

Gambar 1. Alur Algoritma Genetika
A. Mencari Indeks Masa Tubuh

Untuk menghitung indeks masa tubuh dapat dihitung dengan rumus:

$$
\text { IMT }=\frac{\text { Berat Badan }(\mathrm{kg})}{\text { Tinggi Badan x Tinggi Badan (m) }}
$$

Berdasarkan studi kasus yang kami ambil, maka penghitungannya adalah sebagai berikut :

$$
\text { IMT }=\frac{55}{1,75 \times 1,75}=17 \text { (kurus ) }
$$

\section{B. Mencari Berat Badan Ideal}

Untuk menghitung berat badan ideal dapat dihitung dengan rumus :

$\mathrm{BB}$ Ideal $=(\mathrm{TB}-100)-(10 \%(\mathrm{~TB}-100)$

Jika diimplementasikan pada studikasus, maka penghitungannya adalah sebagai berikut :

$\mathrm{BB}$ Ideal $=(175-100)-(10 \%(175-100)$

$=75-7,5$

$=67,5$

\section{Mencari Kebutuhan Kalori Harian}

Untuk menghitung jumlah kalori yang di butuhkan dapat dihitung dengan rumus :

BMR Pria $=66+(13,7 \times$ berat badan $)+(5 x$ tinggi badan $)-$ $(6,8 \times$ usia $)$

BMR Wanita $=655+(9,6 \mathrm{x}$ berat badan $)+(1,8 \mathrm{x}$ tinggi badan $)-(4,7 \times$ usia $)$

Jika diimplementasikan pada studikasus, maka penghitungannya adalah sebagai berikut :

BMR Pria $=66+(13,7 \times 55)+(5 \times 175)-(6,8 \times 22)$

$=1.549$.

Karena memiliki indeks masa yang tergolong kurang, maka kalori yang dibutuhkan ditambah $300 \mathrm{kkl}$ untuk meningkatkan berat badan menuju berat badan ideal .

\section{HASIL DAN PEMBAHASAN}

Pertama-tama, dilakukan pengkodean. Untuk tiap menu makanan yang tercantum pada tabel III, kami mengubah nomor urutnya dari bilangan desimal menjadi bilangan biner. Contohnya menu dengan nomor urut 5, maka memiliki bilangan biner 101 .

Kemudian kami membentuk populasi awal secara acak. Tiap kromosom pada populasi awal terdiri dari tiga waktu makan, dan tiap waktu makan terdiri dari tiga jenis makanan, sebagaimana tertera pada Tabel III. 
TABEL III

POPULASI AWAL

\begin{tabular}{|c|c|c|c|c|c|c|c|c|c|c|c|c|c|}
\hline \multirow{2}{*}{$\frac{\text { Ennoun }}{1}$} & \multicolumn{3}{|c|}{ Maton pad } & \multicolumn{3}{|c|}{ Vaba } & \multicolumn{3}{|c|}{ NibnMitan } & \multicolumn{2}{|c|}{ wow Has } & \multicolumn{2}{|c|}{ 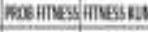 } \\
\hline & III & $\mathrm{kt}$ & $\mathrm{m}$ & tis & III & $\mathrm{mo}$ & $\mathrm{m}$ & $\mathrm{m}$ & $\mathrm{m}$ & & & & \\
\hline & 1 & 1. & 5 & 2 & 1 & 4 & 1 & 1. & 1 & 1216 & 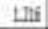 & 2116 & L117 \\
\hline & 或 & 诸 & 13 & iiI & in & 13 & E: & 30 & 27 & & & & \\
\hline \multirow[t]{3}{*}{2} & Ii) & a & 11I & (x) & 11) & $\mathrm{m}$ & II & 100. & m & & & & \\
\hline & 1 & 3 & 1 & 4 & $t$ & 3 & 1 & 4 & 4 & 里 & 漹 & thet & Lat \\
\hline & 132 & w. & as & 를 & 且 & 1.6 & $\pi$ & 58 & III & & & & \\
\hline \multirow[t]{3}{*}{1} & in & III & et & (112) & in & (if) & III & III. & Hit & & & & \\
\hline & f & 7 & $\mathrm{I}$ & 2. & 2 & 2 & 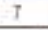 & 1 & 3 & 198 & LIS: & 2,10 & $a x$ \\
\hline & $12]$ & i6: & $\Delta 7$ & 피 & 2 & [15] & I & 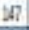 & III & & & & \\
\hline \multirow[t]{3}{*}{4} & III & it) & tit & iti - & iti & IIII & $m$ & mit & $\mathrm{ut}$ & & & & \\
\hline & 7 & 2. & 2 & 1 & $T$ & 6 & 1 & 1 & 1 & Lin & 118 & 2.17 & LUT \\
\hline & 교. & $x$ & 97 & in] & it & 世 & 프 & 48: & *a & & & & \\
\hline \multirow[t]{3}{*}{5} & $\mathrm{Mi}$ & m & etI & ret. & $\mathrm{x}$ & $\mathrm{w}$ & Iit & 131 & tii & & & & \\
\hline & 1 & 4 & 3 & 1 & 1 & 3 & 1 & 1 & 2 & 9.4 & 54 & tom & Ha \\
\hline & 15] & $\mathrm{z}$ & Br & 118 & 3 & 118 & 표 & w) & DI & & & & \\
\hline \multirow[t]{3}{*}{1} & $\underline{L}$ & in & in & IiI) & in & we & 些 & III & 地 & & & & \\
\hline & 1 & 6 & 5 & 1. & 1 & 1 & 4 & $I$ & 4 & 98 & 해 & เต็) & 새밈 \\
\hline & II & 5 & 15 & 52 & 业 & 10 & EI & 660 & III & & & & \\
\hline \multirow[t]{3}{*}{1} & III & tit. & in & t11 & in & ie & III & $\mathrm{m}$ & tas & & & & \\
\hline & 7 & 1 & $i$ & 1. & $T$ & 1. & $\mathrm{I}$ & 1. & 1 & 115 & L156 & 21:T] & Li] \\
\hline & I & เด & 18 & i11 & H & 15! & it & 20 & $\mathrm{~g}$ & & & & \\
\hline \multirow[t]{3}{*}{8} & Q & 20 & III & $2 \mathrm{xt}$ & $x$ & $\mathrm{~m}$ & $m$ & 피 & III & & & & \\
\hline & 1 & 4 & 3 & 5 & 1 & 3 & $t$ & $\mathrm{~T}$ & 1 & 24 & $\Delta 4$ & 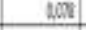 & 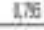 \\
\hline & 13] & w & 표 & $\pi$ & 31 & $z$ & 픈 & $\%$ & III & & & & \\
\hline \multirow[t]{3}{*}{1} & 치 1 & w & till & iiI) & $x$ & (III) & In & III. & 112 & & & & \\
\hline & 1 & 4 & 2 & 3 & 1 & 3 & 4 & 1 & 6 & 54 & ss & 1,04 & th \\
\hline & 15] & 5 & 197 & i] & 站 & 111 & 还 & 27 & III) & & & & \\
\hline \multirow[t]{4}{*}{ B. } & tiv & I1 & w & iit) & 15. & tit & I1 & 200 & Is & & & & \\
\hline & $I$ & 6 & 1 & 3 & 1 & 3 & $f$ & 4 & 5 & $1 \mathrm{IJ}$ & LIB & 211 & bor \\
\hline & 11 & in & 20 & in & 2 & 111] & III & 38 & 115 & & & & \\
\hline & & & & & & & & & & & 1230 & 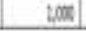 & \\
\hline
\end{tabular}

Kemudian diseleksi. Awalnya dibangkitan bilangan acak sebanyak populasi, hasilnya tertera di Tabel IV.

TABEL IV

BILANGAN ACAK

\begin{tabular}{|r|c|r|r|r|r|r|r|r|c|}
\hline N0 & Bilacak & N0 & Bilacak & N0 & Bilacak & N0 & Bilacak & N0 & Bilacak \\
\hline 1 & 0,791 & 2 & 0,495 & 3 & 0,313 & 4 & 0,195 & $\mathbf{5}$ & 0,097 \\
\hline 6 & 0,528 & 7 & 0,206 & 8 & 0,107 & 9 & 0,190 & 10 & 0,807 \\
\hline
\end{tabular}

Kemudian dilakukanpengurutan tiap kromosom berdasrkan kedekatannya dengan hasil bilangan acak. Contohnya bilangan acak 0,791 paling dekat dengan kromosom 8, sehingga kromosom 8 menempati urutan pertama, begitu juga seterusnya, hingga terbentuk populasi seperti tercantum pada Tabel V.

TABEL V

\section{POPULASI PASCA SELEKSI}

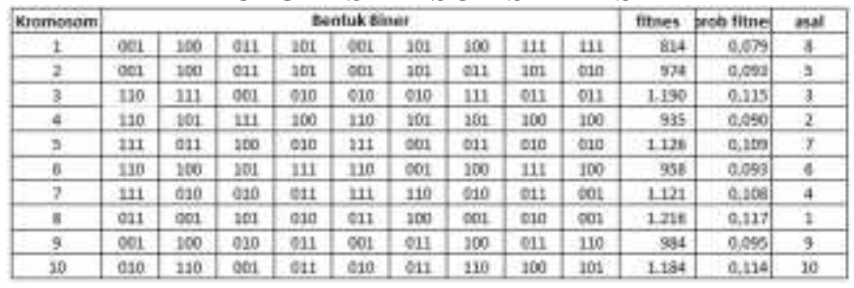

Kemudian dilakukan crossover, dengan peluang crossoveradalah 0,40. Terlebih dahulu membangkitkan bilangan acak sebanyak populasi untuk menentukan kromosom mana yang akan di-crossover, hasilnya tertera pada Tabel VI.
TABEL VI

BILANGAN ACAK

\begin{tabular}{|r|r|r|r|r|r|r|r|r|r|}
\hline N0 & Bil.acak & N0 & Bilacak & N0 & Bil.acak & N0 & Bil.acak & N0 & Bil.acak \\
\hline $\mathbf{1}$ & 0,056 & $\mathbf{2}$ & 0,045 & $\mathbf{3}$ & 0,513 & $\mathbf{4}$ & 0,095 & $\mathbf{5}$ & 0,797 \\
\hline $\mathbf{6}$ & 0,028 & $\mathbf{7}$ & 0,564 & $\mathbf{8}$ & 0,472 & $\mathbf{9}$ & 0,490 & $\mathbf{1 0}$ & 0,007 \\
\hline
\end{tabular}

Terpilih kromosom 1, 2, 4, dan 6, karena memiliki bilangan acak kurang dari 0,40. Crossover dilakukan setelah posisi ketiga dalam kromosom, seperti yang terlihat pada Tabel VII.

TABEL VII

HASIL CROSSOVER

\begin{tabular}{|l|l|l|l|l|l|l|l|l|l|}
\hline 1 & $\mathbf{0 0 1}$ & $\mathbf{1 0 0}$ & $\mathbf{0 1 1}$ & 101 & 001 & 101 & 011 & 101 & 010 \\
\hline 2 & 001 & 100 & 011 & $\mathbf{1 0 1}$ & $\mathbf{0 0 1}$ & $\mathbf{1 0 1}$ & $\mathbf{1 0 0}$ & $\mathbf{1 1 1}$ & $\mathbf{1 1 1}$ \\
\hline 4 & $\mathbf{1 1 0}$ & $\mathbf{1 0 1}$ & $\mathbf{1 1 1}$ & 111 & 110 & 001 & 100 & 111 & 100 \\
\hline 6 & 110 & 100 & 101 & $\mathbf{1 0 0}$ & $\mathbf{1 1 0}$ & $\mathbf{1 0 1}$ & $\mathbf{1 0 1}$ & $\mathbf{1 0 0}$ & $\mathbf{1 0 0}$ \\
\hline
\end{tabular}

Setelah dilakukan crossover, maka kromosom 1, 2, 4, dan 6 memiliki nilai fitness yang lebih besar dari sebelumnya, seperti terlihat di Tabel VIII.

TABEL VIII

POPULASI HASIL CROSSOVER

\begin{tabular}{|c|c|c|c|c|c|c|c|c|c|c|c|c|c|}
\hline Kronosom & \multicolumn{9}{|c|}{ Bentuk Biner } & \multirow{2}{*}{$\begin{aligned} \text { kelori } \\
924 \\
\end{aligned}$} & \multicolumn{2}{|c|}{ fitres prob fithe: } & \multirow{2}{*}{$\frac{25 a l}{8}$} \\
\hline & 021 & 100 & 011 & 101 & 001 & 101 & 100 & 111 & 111 & & 914 & 0,683 & \\
\hline 2 & 001 & 100 & 011 & 101 & 001 & 101 & 011 & 111 & 010 & 1.237 & 1237 & 0,112 & 5 \\
\hline 3 & 110 & 111 & $\mathrm{COC1}$ & 010 & 111 & 001 & 011 & 02 & 010 & 1.190 & 1.190 & 0,108 & 3 \\
\hline 4 & 110 & 101 & 111 & 100 & 110 & 101 & 101 & 10 & 100 & 1.121 & 1.121 & 0,101 & 2 \\
\hline 5 & 111 & 011 & 100 & 010 & 010 & 010 & 111 & 011 & 011 & 1.125 & 1.126 & 0,102 & 7 \\
\hline 6 & 110 & 100 & 101 & 111 & 110 & 001 & 100 & 111 & 100 & 953 & 958 & 0,687 & 6 \\
\hline 7 & 111 & 010 & 010 & 010 & 011 & 100 & 021 & 020 & $\mathrm{CO1}$ & 1.121 & 1.121 & 0,101 & 4 \\
\hline 8 & 011 & W1 & 101 & 011 & 111 & 110 & 0100 & 011 & $\ll 1$ & 1.225 & 1216 & 0,110 & 1 \\
\hline 9 & 001 & 100 & 010 & 011 & 001 & 011 & 100 & 011 & 110 & 934 & 984 & 0,085 & 9 \\
\hline 10 & ons & 110 & $\mathrm{COC}$ & 011 & 010 & 011 & 110 & 10 & 101 & 1.134 & 1.184 & 0,107 & 10 \\
\hline & & & & & & & & & & & 11.061 & 1 & \\
\hline
\end{tabular}

Selanjutnya dilakukan mutasi dengan peluang mutasi 0,01, dengan telebih dulu membangkitkan nilai acak sebanyak empat untuk masing-masing kromosom, karena pada mutasi ini hanya akan melakukan mutasi pada empat bit pertama kromosom, hasil pembangkitan tertera pada Tabel IX. 
TABEL IX

BILANGAN ACAK

\begin{tabular}{|c|c|c|c|c|c|c|c|}
\hline \begin{tabular}{|l|} 
NO \\
\end{tabular} & Bil.acak & NO & Bil.acak & NO & Bil.acak & NO & Bil.acak \\
\hline \multicolumn{8}{|c|}{ Kromosom 1} \\
\hline 1 & 0,056 & 2 & 0,045 & 3 & 0,513 & 4 & 0,095 \\
\hline \multicolumn{8}{|c|}{ Kromosom 2} \\
\hline 1 & 0,056 & 2 & 0,045 & 3 & 0,513 & 4 & 0,095 \\
\hline \multicolumn{8}{|c|}{ Kromosom 3} \\
\hline 1 & 0,056 & 2 & 0,045 & 3 & 0,513 & 4 & 0,095 \\
\hline \multicolumn{8}{|c|}{ Kromosom 4} \\
\hline 1 & 0,056 & 2 & 0,045 & 3 & 0,513 & 4 & 0,095 \\
\hline \multicolumn{8}{|c|}{ Kromosom 5} \\
\hline 1 & 0,056 & 2 & 0,045 & 3 & 0,000 & 4 & 0,095 \\
\hline \multicolumn{8}{|c|}{ Kromosom 6} \\
\hline 1 & 0,056 & 2 & 0,765 & 3 & 0,453 & 4 & 0,234 \\
\hline \multicolumn{8}{|c|}{ Kromosom 7} \\
\hline 1 & 0,056 & 2 & 0,045 & 3 & 0,000 & 4 & 0,095 \\
\hline \multicolumn{8}{|c|}{ Kromosom 8} \\
\hline 1 & \begin{tabular}{ll|}
0,056 \\
\end{tabular} & 2 & 0,045 & 3 & 0,513 & 4 & 0,095 \\
\hline \multicolumn{8}{|c|}{ Kromosom 9} \\
\hline 1 & 0,056 & 2 & 0,045 & 3 & 0,513 & 4 & 0,095 \\
\hline \multicolumn{8}{|c|}{ Kromosom 10} \\
\hline 1 & 0,000 & 2 & 0,045 & 3 & 0,056 & 4 & 0,095 \\
\hline
\end{tabular}

Terpilihlah bit ketiga pada kromosom 5 dan 6, serta bit pertama pada kromosom kesepuluh, karena memiliki nilai lebih kecil dari peluang mutasi. Hasil mutasi dapat dilihat di Tabel X.

TABEL X

POPULASI HASIL MUTASI

\begin{tabular}{|c|c|c|c|c|c|c|c|c|c|c|c|c|c|}
\hline Kicmosom & \multicolumn{9}{|c|}{ Bernuk Hiner } & balsí & Panes & noblitire & asd \\
\hline & 001 & 100 & 04 & wa & 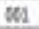 & 101 & 100 & III & iti & 914 & 244 & 0,095 & 8 \\
\hline 4 & 面 & 100 & all & $2 \pi 1$ & $\mathrm{WM}$ & 101 & inI & 进 & 90 & 1.237 & $1.23 \mathrm{~J}$ & 0,10 & 5 \\
\hline 3 & 110 & III & $\omega t$ & 42 & 111 & $\infty 1$ & ot1 & 010 & 010 & 1190 & 1.15 & 0,106 & 1 \\
\hline a) & 110 & 101 & III & $2 x$ & 235 & 101 & 101 & 100 & 10 & 1121 & 1.221 & $0.100]$ & 2 \\
\hline 3 & 110 & OII & 10 & $4 \mathrm{~s}$ & 02 & 020 & III & on & on & 1306 & 1.206 & 8,107 & 7 \\
\hline 6 & IiD & 1000 & tai. & in & 130 & id & 100 & in & 100 & 998 & $95 \mathrm{t}$ & toass & $d$ \\
\hline 7 & 110 & 010 & 010 & as & ต11 & 100 & 001 & 010 & 001 & 1201 & $12 \%$ & 0.107 & 4 \\
\hline 8 & 0II & $\infty$ & 101 & oni & 111 & 1110 & 010 & वप & का & 1216 & 1.226 & Q.1003 & 1 \\
\hline 9 & $\infty$ & 100 & ato & oII & 001 & 011 & 100 & oII & 110 & 964 & 94 & 0.039 & 3 \\
\hline 10 & 110 & 110 & 001 & ass & tab & 011 & 110 & 100 & 101 & 1108 & 1.194 & 0,1007 & 26 \\
\hline & & & & & & & & & & & 11225 & & \\
\hline
\end{tabular}

\section{KESIMPULAN}

Dari penghitungan di atas, dapat diperoleh statistik sebagaimana tercantum pada Tabel XI.

TABEL XI

STATISTIK HASIL

\begin{tabular}{|l|l|l|l|}
\hline $\begin{array}{l}\text { Generasi } \\
\text { ke }\end{array}$ & $\begin{array}{l}\text { Fitness } \\
\text { Terbaik }\end{array}$ & $\begin{array}{l}\text { Fitness } \\
\text { Terburuk }\end{array}$ & $\begin{array}{l}\text { Rata- } \\
\text { rata }\end{array}$ \\
\hline 1. & 1.216 & 814 & 1.035 \\
\hline 2. & 1.237 & 914 & 1.123 \\
\hline
\end{tabular}

Dapat dilihat bahwa terjadi kenaikan rata-rata jumlah kalori dari generasi pertama ke generasi kedua, sebesar 88 kkal. Sehingga dapat disimpulkan bahwa generasi kedua menghasilkan individu-individu yang lebih baik dibandingkan dengan generasi sebelumnya. Dengan tiap menu makanan dikonsumsi bersamaan dengan nasi sebanyak tiga kali dan total kalori nasi sebesar $612 \mathrm{kkal}$, maka dari generasi kedua terdapat kromosom 2 yang memiliki nilai kalori 1.849kkal, sesuai dengan kebutuhan gizi yang dianjurkan. Pada generasi sebelumnya, tidak terdapat menu makanan yang memenuhi kebutuhan gizi yang dianjurkan.

Pada penelitian selanjutnya, penghitungan ini dapat dilanjutkan untuk menemukan lebih banyak kombinasi makanan yang memiliki nilai kalori yang lebih tinggi atau sama dengan 1.849 kkal.

\section{REFERENSI}

[1] Direktorat Jenderal Bina Gizi dan KIA, Pedoman Gizi Seimbang. Jakarta: Kementerian Kesehatan RI, 2014.

[2] KEMENTERIAN KESEHATAN REPUBLIK INDONESIA, "HASIL UTAMA RISKESDAS 2018.” 2018.

[3] Badan Penelitian dan Pengembangan Kesehatan Kementerian Kesehatan RI, "Riset Kesehatan Dasar.” 2010.

[4] R. A. Permata and D. Triyanto, "APLIKASI PENYUSUN MENU MAKANAN UNTUK PENCEGAHAN HIPERKOLESTEROLEMIA MENGGUNAKAN ALGORITMA GENETIKA,” vol. 04, p. 11, 2016.

[5] D. Airyn, I. Cholissodin, and B. D. Setiawan, "Optimasi Menu Makanan Untuk Pemenuhan Gizi Penderita Kanker Dengan Algoritme Genetika," p. 8

[6] Direktorat Jenderal Bina Kesehatan Masyarakat, Pedoman Praktis Terapi Gizi Medis. Jakarta: Departemen Kesehatan RI, 2003.

[7] Muliadi, "PEMODELAN ALGORITMA GENETIKA PADA SISTEM PENJADWALAN PERKULIAHAN PRODI ILMU KOMPUTER UNIVERSITAS LAMBUNG MANGKURAT," Kumpulan jurnaL Ilmu Komputer (KLIK), vol. 01, no. 01, p. 12, Sep. 2014.

[8] N. I. Widiastuti, "ALGORITMA GENETIK PADA MASALAH TATA LETAK MESIN DENGAN PENGKODEAN KROMOSOM UNTUK UKURAN MESIN YANG BERBEDA-BEDA,” p. 8.

[9] R. A. Permata and D. Triyanto, "APLIKASI PENYUSUN MENU MAKANAN UNTUK PENCEGAHAN HIPERKOLESTEROLEMIA MENGGUNAKAN ALGORITMA GENETIKA," vol. 04, p. 11, 2016.

[10]Z. Michalewicz, Genetic Algorithms + Data Structures, Evolution Programs. Verlag: Springer, 1996.

[11]S. Bali, "PENERAPAN METODE ALGORITMA GENETIKA UNTUK PENJADWALAN MENGAJAR,” vol. 8, no. 1, p. 8, 2017.

[12] Samaher and W. F. Mahmudy, "PENERAPAN ALGORITMA GENETIKA UNTUK MEMAKSIMALKAN LABA PRODUKSI JILBAB," Journal of Environmental Engineering \& Sustainable Techonology, vol. 2, no. 1, pp. 06-11, Jul. 2015.

[13]N. L. A. Ayuningrum and F. Y. Saptaningtyas, "IMPLEMENTASI ALGORITMA GENETIKA DENGAN VARIASI CROSSOVER DALAM PENYELESAIAN CAPACITATED VEHICLE ROUTING PROBLEM WITH TIME WINDOWS (CVRPTW) PADA PENDISTRIBUSIAN AIR MINERAL,” p. 11.

[14] Riska Ayu Permata, Dedi Triyanto, Ilhamsyah, APLIKASI PENYUSUN MENU MAKANAN UNTUK PENCEGAHAN HIPERKOLESTEROLEMIA MENGGUNAKAN ALGORITMA GENETIKA, Jurnal Coding Sistem Komputer Untan ISSN: 2338-493X Volume 04, No.2 (2016), hal. 96-106 